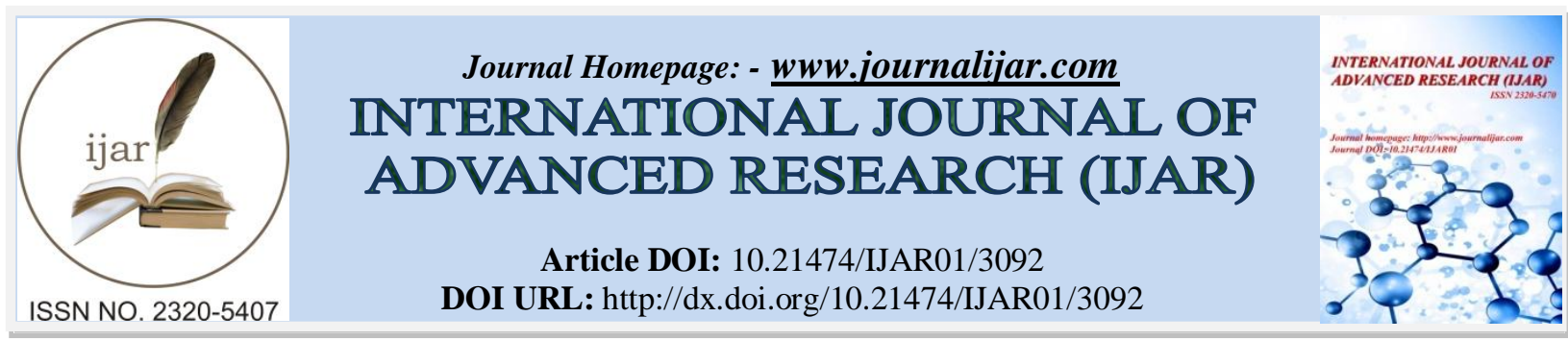

RESEARCH ARTICLE

\title{
THE DISTRIBUTION OF ABO BLOOD GROUPS AND RHESUS FACTOR AMONG REGULAR BLOOD DONORS IN AL-MADINAH AL-MONAWARAH , SAUDI ARABIA 2016.
}

*Abdullah Mohammed AlBilali, Omar Badr AlFraidy, Hatem Hussein AlHarbi, Sultan Jameel Mhros, Hussam Atallah AlSayed, Khaled Majdi Tolah, Abduljawad Salem AlHarbi and Azhar AbdulRahman

Kurban.

Taibah University.

\section{Manuscript Info}

Manuscript History

Received: 03 November 2016

Final Accepted: 28 December 2016

Published: January 2017

\section{Abstract}

Objectives:The study aimed to determine the distribution of $\mathrm{ABO}$ and Rhesus D (RhD)blood groups in Al-Madinah Blood Bank regular donors .

Methods: A cross-sectional study that was carried out at Al-Madinah Blood Bankduring the period from 21 November 2016 to 15 December 2016. The participants were regular blood donors, and the samples were collected during the time of blood donation.

Results: The frequencies of $\mathrm{ABO}$ groups were $45.3 \%$ for $\mathrm{O}$ group, $27.7 \%$ for A group , $18.9 \%$ for B group and $8.1 \%$ for $\mathrm{AB}$ group. For Rhesus factor it was $87.9 \%$ positive and $12.1 \%$ negative.

Copy Right, IJAR, 2016,. All rights reserved.

\section{Introduction:-}

Until now , around 30 blood group systems are recognized according to International Society of Blood Transfusion[1].Among these systems, $\mathrm{ABO}$ an Rh blood group systems has utmost importance. The importance of these two groups is due to the fatal complications that could be encountered in case there was incompatibility between the blood groups during the process of blood transfusion[2]. In addition to that, studies shows relations between blood groups and some diseases [3-9].

In Saudi Arabia, some studies have been done to determine the distribution of $\mathrm{ABO}$ and $\mathrm{Rh}$ group systems . $\mathrm{O}$ group have had the highest incidence in the all-region of the kingdom and $\mathrm{AB}$ group were the lowest, while there was differences in the A and B groups distribution as A group tend to be higher in the west and lower in the east , while B group was higher in the east and lower in the south[10-13] .

\section{Objective:-}

To know the frequencies of $\mathrm{ABO}$ and Rhesus $\mathrm{D}(\mathrm{RhD})$ blood groups in AL-MadinahBlood Bank regular donors and compare our results with the others that carried outin the kingdom.

\section{Methodology:-}

It was a cross-sectional study that was carried out at Al-Madinah blood Bank during the period from 21 November 2016 to 15 December 2016. The subjects were 307 and they were regular blood donors. The sample were collected during the blood donation process after explaining the idea of the research to the subjects and taking the consent from them . Then the ABO blood groups and $\mathrm{Rh}$ factor were determined and the frequencies of the distribution of them were calculated. 


\section{Result:-}

The total number of the subjectswas 307 as 305 were male and 3 were female . 59\% of the participants were Saudis and $41 \%$ were non-Saudis.The non-Saudis nationalities were as following: Pakistani $10.1 \%$, Egyptian 9.1\%, Indian and Yamani each of both were 5.9\% and 10\% were other nationalities. The frequencies of ABO groups for all the sample were $45.3 \%$ for $\mathrm{O}$ group, $27.7 \%$ for A group, 18.9\% for B group and $8.1 \%$ for $\mathrm{AB}$ group. For RhD it was $87.9 \%$ positive and $12.1 \%$ negative. Overall frequency of $\mathrm{ABO}$ and Rhesus blood groups were as following : $38.4 \% \mathrm{O}+, 25.1 \% \mathrm{~A}+, 16.9 \% \mathrm{~B}+, 6.8 \% \mathrm{O}-, 6.5 \% \mathrm{AB}+, 2.6 \% \mathrm{~A}-, 2.0 \% \mathrm{~B}-$ and $1.6 \% \mathrm{AB}-$. For Saudis, ABO frequencies were : $\mathrm{O} 47.0 \%$, A $28.2 \%$, B $15.5 \%$ and $\mathrm{AB} 9.4 \%$, while the $\mathrm{RhD}$ were positive in $87.3 \%$ and negative in $12.7 \%$. The overall frequencies for Saudis were O+ 38.1\%, A+ 26.5\%, B+ 14.4\%, O- 8.8\%, AB+ 7.7\% , Aand $\mathrm{AB}-1.7 \%$ for each of them and $\mathrm{B}-1.1 \%$.

THE NATIONALITIES OF PARTICIPANTS

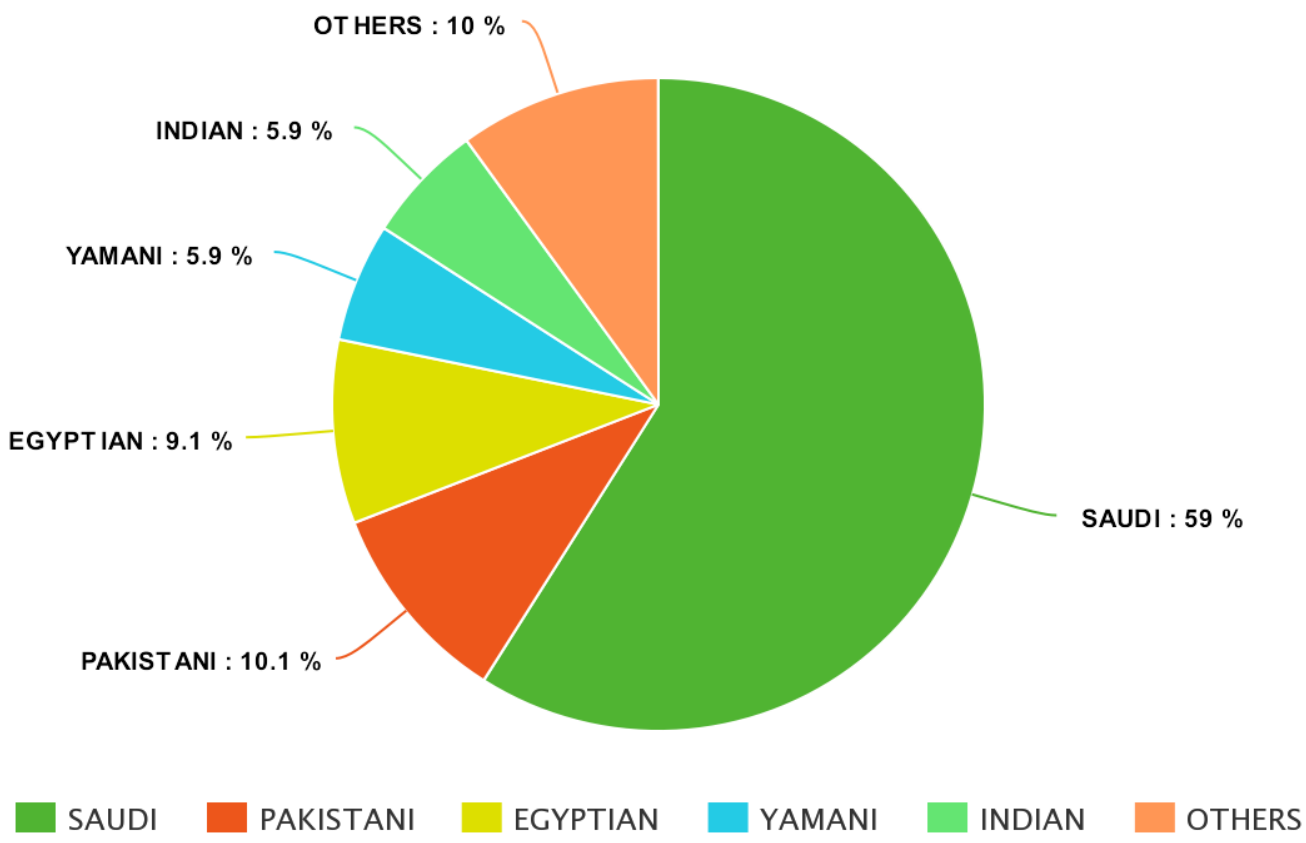


Frequencies of $A B O$ groups in the whole sample

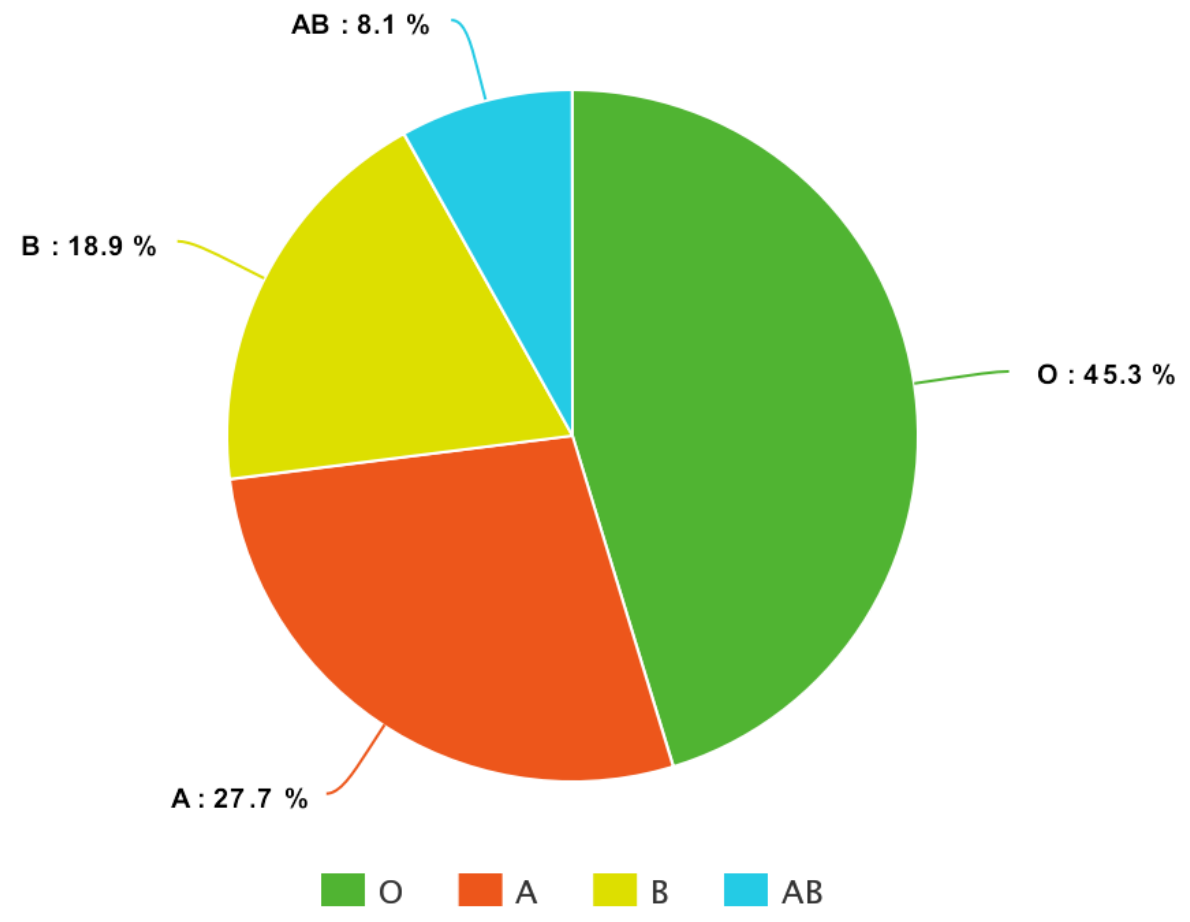

meta-chart.com

THE PERCENTAGE OF Rh(D) FACTOR IN THE WHOLE SAMPLE

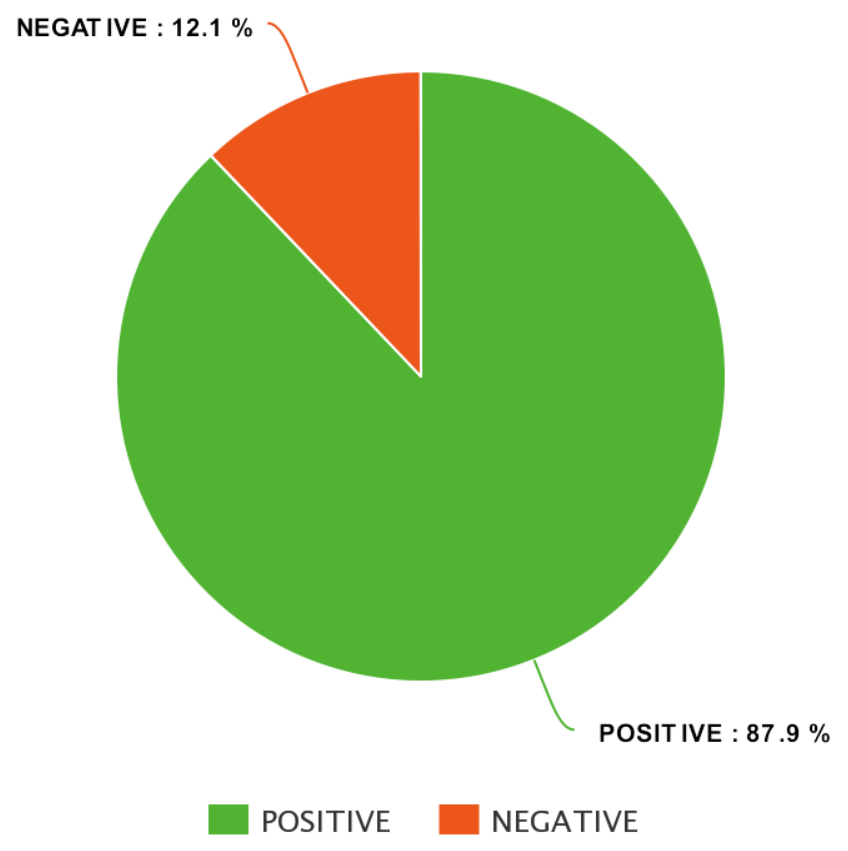

meta-chart.com 
THE FREQUENCIES OF OVERALL ABO AND Rh(D) GROUPS IN THE WHLE SAMPLE

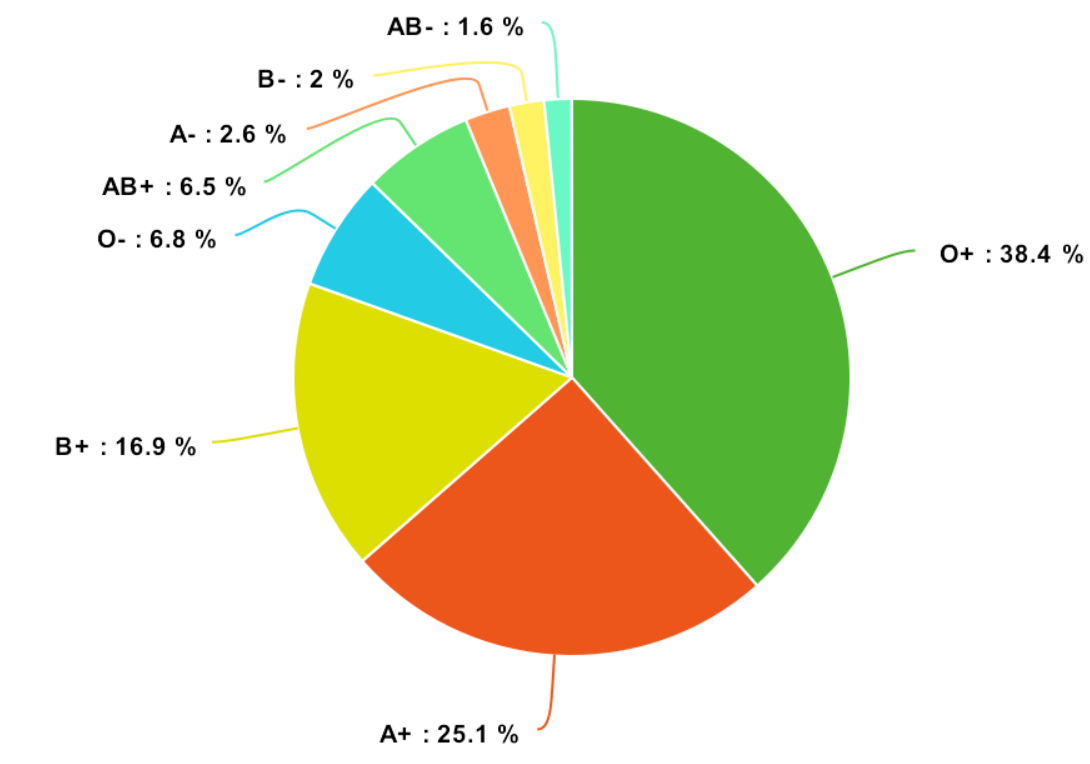

$\mathrm{O}+\square \mathrm{A}+\square \mathrm{B}+\square \mathrm{O}-\square \mathrm{AB}+\square \mathrm{A}-\square \mathrm{B}-\square \mathrm{B}-$

meta-chart.com

THE FREQUENCIES OF ABO GROUPS AMONG SAUDIS

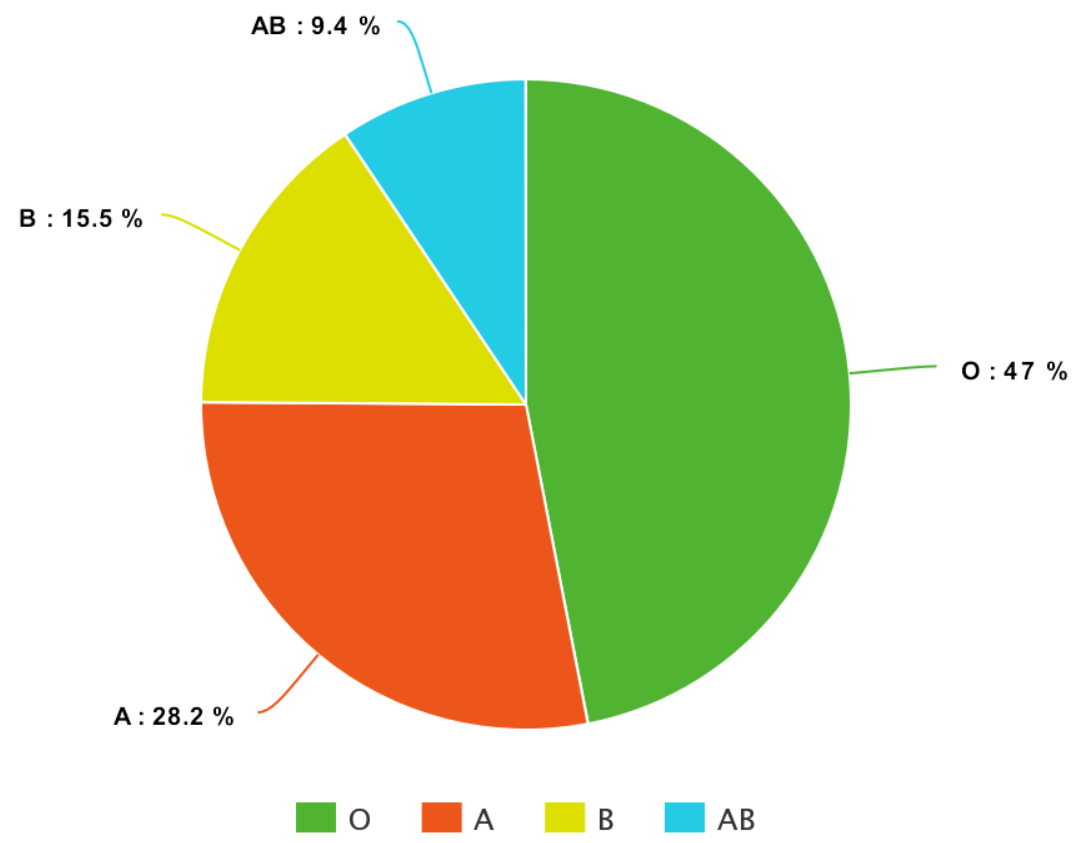

meta-chart.com 
THE PERCENTAGE OF Rh(D) FACTOR AMONG SAUDIS

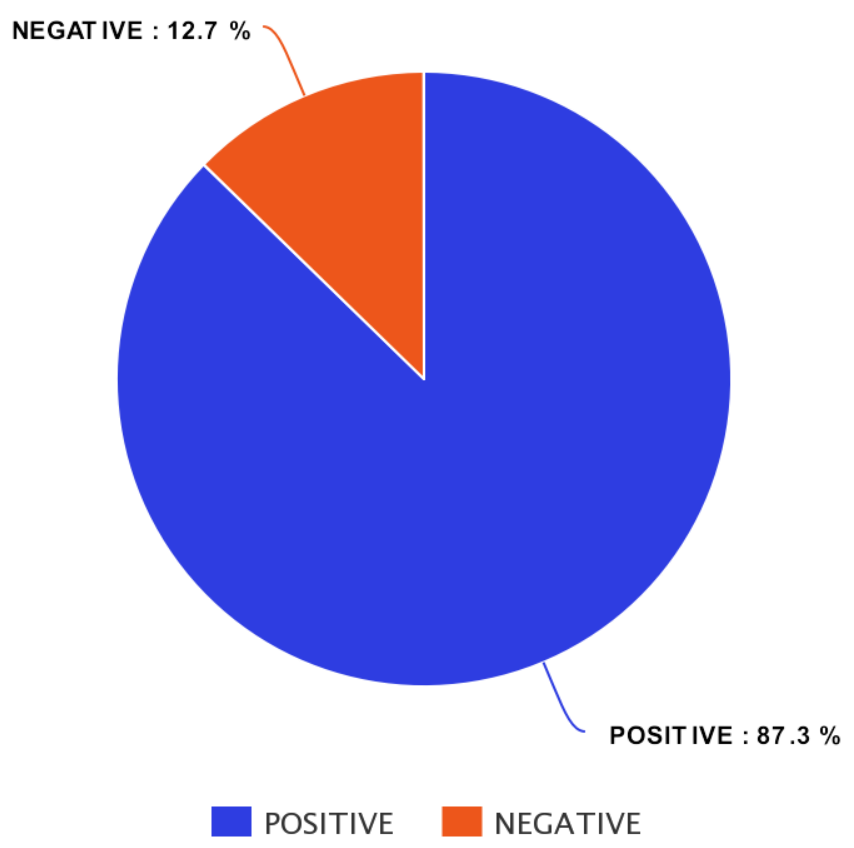

meta-chart.com

THE FREQUENCIES OF OVERALL ABO AND Rh(D) GROUPS AMONG SAUDIS

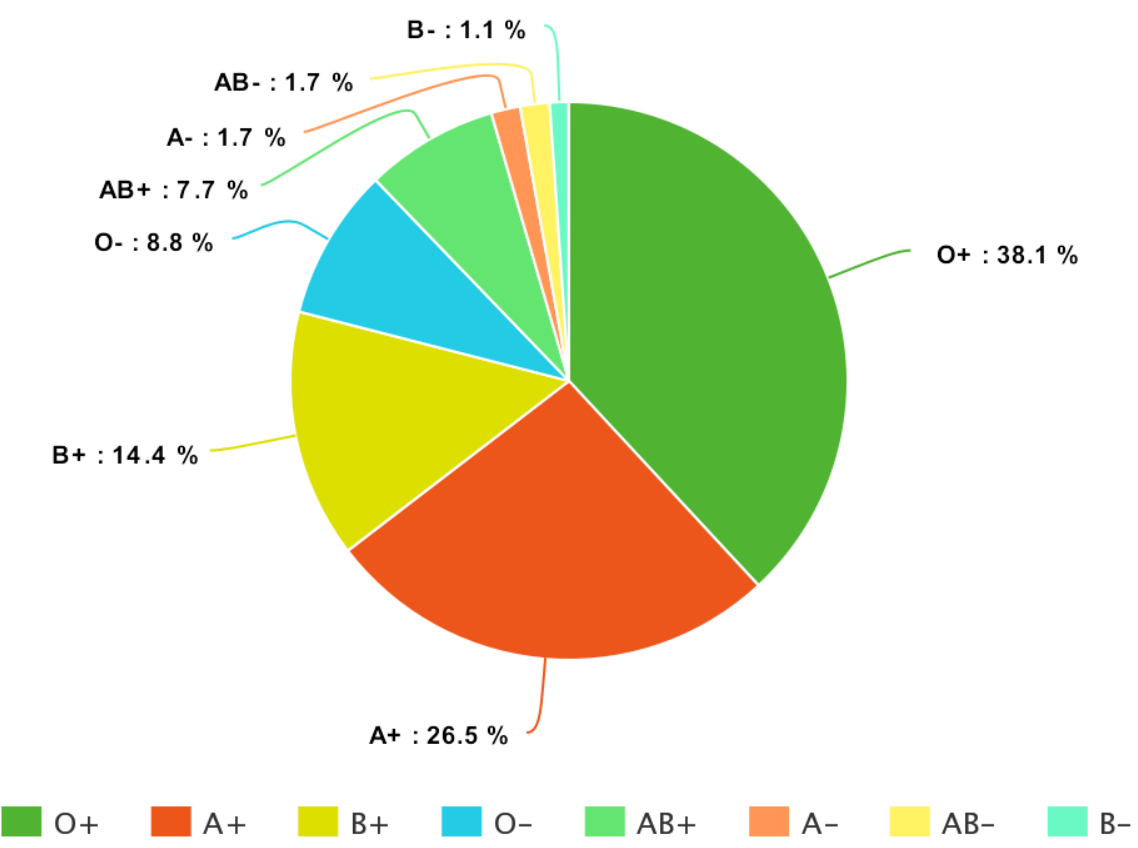

meta-chart.com 


\section{Discussion:-}

The results of this study showed agreement with other studies that done in the kingdom in that $\mathrm{O}$ group has the highest prevalence and $\mathrm{AB}$ is the lowest[10-13]. In addition, it showed agreement in that $\mathrm{A}$ group has higher prevalence among Saudis in Al-Madinah (northwest) in compare with eastern region of the kingdom [10-12].

\section{Conclusion:-}

The study shows similarity in the frequencies of $\mathrm{ABO}$ and $\mathrm{Rh}$ blood groups with other studies that was done in Arabian Peninsula area .

Conflict of interest and Funding:-

The investigators have no conflict of interest to disclose, and they have not received any research grant from any organization for this project .

\section{Acknowledgment:-}

To:-

1. Mr.Majed AlAhmadi the head of AL Madinah Regional Laboratory .

2. Mr. Fayez AlSehli the head of AL Madinah Blood Bank.

3. Mr. Ibrahem AlNugrani .

4. ALL the workers in the Al Madinah Blood Bank

\section{References:}

1. Logdberg L, Reid ME, Zelinski T: Human blood group genes 2010: chromosomal locations and cloning strategies revisited. Transfusion medicine reviews 2011, 25(1):36-46.

2. Mitra R, Mishra N, Rath GP: Blood groups systems. Indian Journal of Anaesthesia 2014, 58(5):524-528.

3. Anstee DJ: The relationship between blood groups and disease. Blood 2010, 115(23):4635-4643.

4. Gates MA, Wolpin BM, Cramer DW, Hankinson SE, Tworoger SS: ABO blood group and incidence of epithelial ovarian cancer. International journal of cancer 2011, 128(2):482-486.

5. Hiltunen LM, Laivuori H, Rautanen A, Kaaja R, Kere J, Krusius T, Paunio M, Rasi V: Blood group AB and factor V Leiden as risk factors for pre-eclampsia: a population-based nested case-control study. Thrombosis research 2009, 124(2):167-173.

6. Tufano A, Coppola A, Nardo A, Bonfanti C, Crestani S, Cerbone AM, Franchini M: Non-O blood group as a risk factor for cerebral vein thrombosis. Thrombosis and haemostasis 2013, 110(1):197-199.

7. Wang DS, Chen DL, Ren C, Wang ZQ, Qiu MZ, Luo HY, Zhang DS, Wang FH, Li YH, Xu RH: ABO blood group, hepatitis B viral infection and risk of pancreatic cancer. International journal of cancer 2012, 131(2):461-468.

8. Wiggins KL, Smith NL, Glazer NL, Rosendaal FR, Heckbert SR, Psaty BM, Rice KM, Lumley T: ABO genotype and risk of thrombotic events and hemorrhagic stroke. Journal of thrombosis and haemostasis : JTH 2009, 7(2):263-269.

9. Zhang H, Mooney CJ, Reilly MP: ABO Blood Groups and Cardiovascular Diseases. International journal of vascular medicine 2012, 2012:641917.

10. Al-Himaidi AR, Umar M: ABO blood group distribution among Saudi citizens related to their regional and original tribal location. Kuwait J Sc Eng 2002, 29(11):75-81.

11. Bashwari LA, Al-Mulhim AA, Ahmad MS, Ahmed MA: Frequency of ABO blood groups in the Eastern region of Saudi Arabia. Saudi medical journal 2001, 22(11):1008-1012.

12. Ozsoylu S, Alhejaily M: The distribution of ABO and Rh blood groups in the Tabuk region and Medina Munewera, Saudi Arabia. The Turkish journal of pediatrics 1987, 29(4):239-241.

13. Sarhan MA, Saleh KA, Bin-Dajem SM: Distribution of ABO blood groups and rhesus factor in Southwest Saudi Arabia. Saudi medical journal 2009, 30(1):116-119. 